\title{
Trading Control: National Chiefdoms within
}

\section{International Organizations}

Mareike Kleine

LEQS Paper No. 59/2013

March 2013

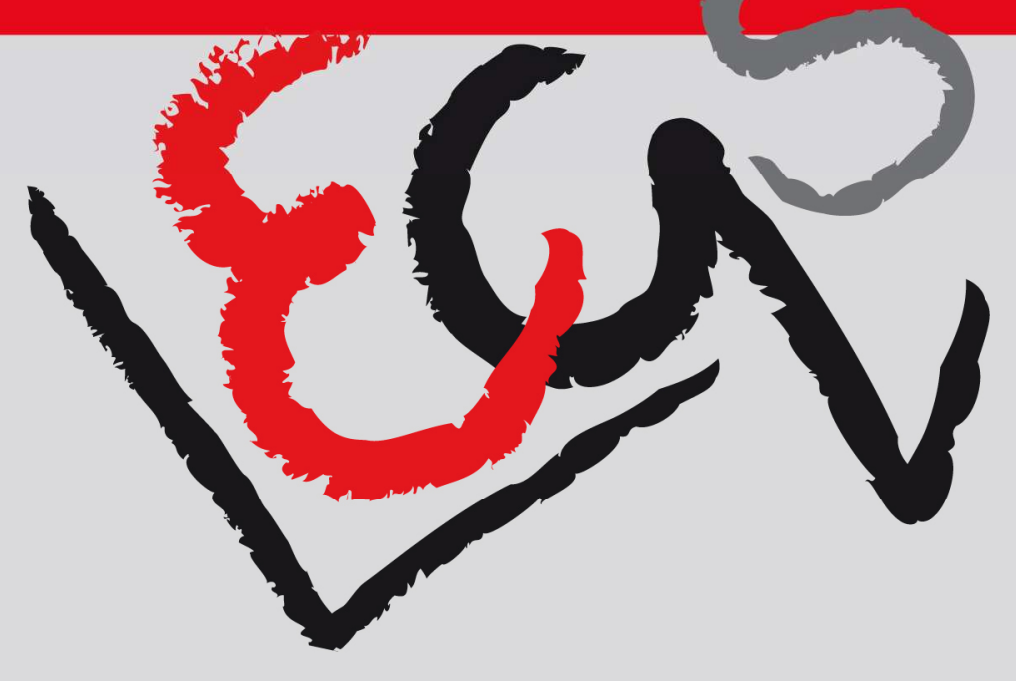




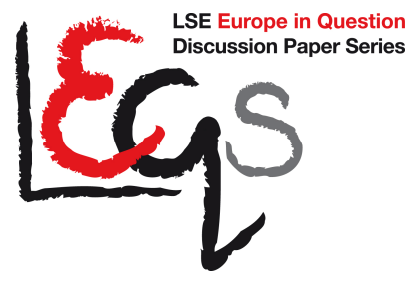

\author{
Editorial Board \\ Dr Mareike Kleine \\ Dr Vassilis Monastiriotis \\ Dr Jonathan White \\ Dr Katjana Gattermann
}

All views expressed in this paper are those of the author and do not necessarily represent the views of the editors or the LSE.

(C) Mareike Kleine 


\title{
Trading Control: National Chiefdoms
}

\section{within International Organizations}

\author{
Mareike Kleine*
}

\begin{abstract}
According to Principal-Agent theory, states (the principal) delegate the implementation of a legalized agreement to an international organization (the agent). The conventional wisdom about states' capacity to control international organizations is that differences among the member states impede control and consequently enhance the agent's autonomy, whereas agreement allows for effective control and limited autonomy. Contrary to this conventional wisdom, this article argues that conflicts among states need not impede effective control. On the contrary: it harbors gains from the exchange of informal control over an organization's divisions. As a result, international organizations exhibit informal spheres of influence, or national chiefdoms. The article demonstrated the theory's plausibility using the example of the EU. It has implications for the literature on delegation and informal governance.
\end{abstract}

* London School of Economics and Political Science European Institute, Houghton St, London WC2A 2AE, UK

Email: m.o.kleine@lse.ac.uk 


\section{Table of Contents}

Abstract

$\begin{array}{ll}\text { Introduction } & 1\end{array}$

The Politics of and within International Organizations 5

A Theory of Informal Spheres of National Influence within $\begin{array}{lr}\text { International Organizations } & 8\end{array}$

The limits of control of international organizations 9

Gains from exchange of control 11

The industrial organization of international bureaucracies 12

Informal Spheres of Influence in the European Union $\quad 14$

The European Commission as an independent agent 14

$\begin{array}{ll}\text { The Commission in reality } & 17\end{array}$

The distribution of posts in the Commission 21

Discussion: National Chiefdoms Outside the EU 23

$\begin{array}{ll}\text { Conclusion } & 25\end{array}$

$\begin{array}{ll}\text { References } & 28\end{array}$ 


\section{Trading Control: National Chiefdoms}

\section{within International Organizations}

\section{Introduction}

According to the treaties, members of the European Commission, the European Union's (EU) principal supranational bureaucracy, are entirely independent in their decisions and take instructions neither from their native country, parties, nor from any other group. Brussels' folk wisdom consequently regards the Commission as a counterbalance to member states' reactionary reflexes that, in the words of an early theorist of European integration, serves to upgrade states' common interests (Haas 1961, 369). In reality, however, nationality seems to play a strong role in the Commission, even if the treaty says otherwise. This became most obvious when the looming accession of new member states to the EU led to calls to reduce the Commission's size by relinquishing the member states' right to nominate a Commissioner. Although they typically argue in favor of the Commission's independence, especially small member states insisted fiercely on retaining "their" Commissioner. The phenomenon is not limited to the EU. As I shall illustrate, there appears to be substantial variation in the extent to which international bureaucracies exhibit national chiefdoms, that is, subdivisions within an international bureaucracy that unofficially "belong" to and are influenced by a certain country.

Although empirical studies sometimes mention the existence of chiefdoms or different cultures within international organizations (Cini 2000), this phenomenon is not easily squared with the way that International Relations 
scholars typically approach international organizations. According to the popular Principal-Agent model, states delegate the authority to implement a legalized interstate agreement to an international bureaucracy. Anticipating that they will be tempted to manipulate their agent, states deliberately shield it from ad-hoc influence. Thus, the act of delegation reifies member states and the international organization as two unitary actors in a principal-agent relationship. Although states set up control mechanisms in order to keep their organization in check, this model does not envisage national influence from inside a bureaucracy. That would be considered an institutional pathology.

There are good arguments for neglecting the study of informal spheres of national influence within international organizations. One is that political posts within a bureaucracy are largely ceremonial. Just like the Department of Administrative Affairs in the British television series "Yes Minister" is in fact run by civil servants, and not by the minister, it is possible that political posts within the Commission or other bureaucracies are prestigious, but unimportant. Another argument against studying national chiefdoms is that certain subdivisions belong to certain countries simply because they have more expertise. Landlocked Austria, for example, might face difficulties coming up with a candidate for the head of the fisheries division. In contrast, I contend that informal spheres of influence are neither pathologies nor insignificant. They arise systematically and are important for understanding how international organizations work day to day.

This article presents a transaction-cost based theory of informal spheres of influence in international organizations. Its central argument is that these spheres result from the implicit exchange of administrative control among governments. Drawing on distributional theories of Congress (Weingast and Marshall 1988), it is based on the assumption that the diversity of interests among states holds gains from the exchange of influence over different 
dimensions of an organization's output. Because governments may renege on delivering their quid pro quo, states enforce these exchanges by granting one another agenda control over their preferred divisions within the international organization - a control that they can use to prevent activism and determine the content of the division's policy. As a result, international organizations exhibit mutually tolerated informal spheres of national influence, or national chiefdoms. A testable implication of this theory is that because member states grant one another agenda control over their most preferred subdivisions, preference outliers with strong interests in the subdivision's policy control national chiefdoms.

The theory has important implications for the literature on delegation and international organization. First, the paper offers a theoretical argument about the limits of Principal-Agent approaches to organizations. If durable exchanges of control among states result in the institutionalization of national chiefdoms within an administration, this administration (agent) cannot be considered a unitary actor in interaction with the member states (principal). Although the approach itself is relatively theory-neutral in the sense that it does not assume actors to hold specific preferences over policies, international relations scholars typically assume that international organizations have a preference for enhancing their autonomy vis-à-vis member states (Hawkins, Lake, Nielson et al. 2006, 9-10, 24-25), and consequently ask whether and how states keep them under control (e.g., Pollack 1997). Similarly, in EU studies prominent models of legislative bargaining typically model the Commission as a unitary actor with invariably strong preferences for deep levels of integration (see, e.g., Garrett and Tsebelis 1996, 280). I argue that its unitary character and preferences are empirical questions that cannot be imputed to an international organization. Politics and bureaucracy interact in more complex ways. 
Second, the paper contributes to a growing body of literature on informal governance within international organizations. Prominent studies in this research agenda attribute this phenomenon to power asymmetries among member states (Stone 2011, ; see, however, Author b), arguing that informal governance allows powerful states to circumvent the formal procedures when they consider their important interests to be at stake. In contrast, this paper presents a transaction cost-based argument for the existence of informal governance, which it attributes to implicit exchange of control within an international organization.

To demonstrate the theory's plausibility, this article presents a case study of appointments and recruitments in the European Commission and a cursory description of practices in other international organizations. Drawing on new material from EU archives and other primary sources about the member states' informal influence as well as secondary analyses of its preferences and appointments, I find that this supranational bureaucracy indeed exhibits divisions that are informally dominated by one or a group of like-minded member states. Corroborating the theory, member states informally grant one another control over those divisions that they prefer intensely.

The article is structured as follows. The following section briefly reviews how today's literature on international organization has come to approach organizations as unitary actors and consequently neglect the politics within them. The second section then presents a theoretical argument for why and under what circumstances we should expect international organizations to exhibit informal spheres of national influence. Using the example of college of Commissioners and their cabinets in the EU, the subsequent section probes the theory's plausibility. I conclude by discussing the applicability of this theory beyond the case of the EU, illustrating the existence of informal 
spheres of influence in other international organizations, and recapitulating the study's theoretical and substantive implications.

\section{The Politics of and within International Organizations}

International organizations can be defined as formal entities that have states as members and possess a permanent secretariat, bureaucracy or some other form of permanent administration (Pevehouse, Nordstrom, and Warnke 2004, 103). Although they are constitutive for international organizations, administrations have received less and less attention as scholarly focus shifted from the politics within to the politics and design of international organizations. Ironically, the principal-agent approach, which places emphasis on the "actorness" of international organization, contributed to the scholarly neglect of organizations. Only recently, the literature on informal governance with its focus on uncodified rules that run in parallel to official procedures has begun to explore the complex interaction between the politics of and within international organizations. The following is a brief overview of the shift in scholarly attention away from organizations and the renewed interests in studies of informal governance.

In the post-war era, it was a central concern for scholars to explore whether the new international organizations such as the World Bank or the United Nations would be able to support the political and economic reconstruction effort. Against the background of the intellectual divide between "idealists" and "realists," who were optimistic or pessimistic in this respect, the focus of research typically lay on the politics within international organizations to 
identify the conditions under which these organizations triumphed over nation states' realpolitikal reflex. ${ }^{1}$

With the deepening of international interdependence in the 1970s, scholars realized that many situations in international politics are characterized not by discord or harmony, but by a combination of mutual dependence and conflict ("mixed motives"). Accordingly, attention shifted to the conditions under which states want to cooperate and accept being constrained by a regime's "norms, principles, rules and procedures." 2 This new focus gradually demoted the study of international organizations proper. "Prior to the study of international regimes," Lisa Martin and Beth Simmons explain in their review of the intellectual history of international organization, "an inquiry into the effects of international institutions meant inquiring into how effectively a particular agency performed its job... When regime analysts looked for effects, these were understood to be outcomes influenced by a constellation of rules rather than tasks performed by a collective international agency" (Martin and Simmons 1998, 737).

International organizations resumed center stage when instead of falling apart, as some scholars had predicted, they became increasingly prominent as the end of the East-West conflict opened up new opportunities to shape the global order. However, their proliferation and increasing significance from the 1990s onwards also raised concerns among some scholars and general public about the accountability of international organizations. Since these discussions resembled debates in American Politics about the autonomy of

\footnotetext{
${ }^{1}$ For example, Ernst Haas' ((1958)) neo-functionalist approach to international integration was inter alia based on the conviction that actors within supranational organizations would persuade national elites to shift their loyalty from the domestic to the supranational level. This stands in contrast to Morgenthau's contention that realpolitik is central

2 This research question allowed scholars to link the discipline to the analysis of institutions in other disciplines. Robert Axelrod ((1984)), for example, introduced game theory to the study of cooperation, and Bob Keohane ((Keohane 1984)) applied transaction cost economics to the study of international regimes.
} 
"runaway" bureaucracies, it was not long until scholars introduced principalagent (P-A) approaches to the study of international organizations. From this perspective, states (the collective principal) delegate the authority to implement a legalized interstate agreement to an international bureaucracy (the agent), and then devise a number of control mechanisms in order to keep the agent in check. ${ }^{3}$ As the following section points out, because it views agents as unitary actors, the principal-agent approach shifted its attention to the interaction between international organizations and its members at the expense of the interaction within the organization itself.

Only recently, the research program on informal governance has begun to explore the complex interaction between interests and organizations in its day-to-day operation. Stone presents a power-based theory of informal governance, arguing that it is the result of a tacit deal between small states and the US concerning the organization's autonomy. In exchange for more favorable formal voting rights in normal times, small states accept that the dominant power assumes informal temporary control of the organization when urgent strategic objectives override its interest in the organization's long-term interests (Stone 2011). Kleine argues that in more symmetric settings such as the European Union (EU), states informal governance in order to prevent otherwise autonomous supranational agents from adopting measures that provoke unmanageable domestic pressure against this organization. It thus gives them the flexibility to manipulate one another's domestic politics of collective action in a way that domestic interests remain constantly aligned in favor of cooperation (Kleine forthcoming-a, forthcoming-b).

\footnotetext{
${ }^{3}$ Applying this approach to the study of EU institutions, Mark Pollack $((1997,129))$ argued that supranational actors' autonomy critically depended on the effectiveness of institutional control mechanisms. A volume edited by Hawkins and colleagues ((2006)) applied the P-A model and some of its extensions to the study of international organizations such as the IMF or the WTO.
} 
In short, studies of the politics within international bureaucracies. This research agenda goes beyond standard P-A approaches in that it explores under what conditions international organizations can in fact be considered autonomous agents. In this respect, however, they have only scratched the surface.

\section{A Theory of Informal Spheres of National Influence within International Organizations}

Why do governments tolerate one another's informal influence over aspects of an international organization? This section presents a transaction costbased theory of national chiefdoms within international organizations. It starts off with the observation of standard P-A models that conflicts among the member states impedes effective state control and enhances the autonomy of international organization, whereas agreement among states on how they want the international organization to act reduces its room for maneuver. Extending this model by allowing for the international organization to comprise multiple issue-areas turns these claims on their head, since multiple issues open up opportunities for gains from exchange of states' support for control. Because deals like this are subject to the problem of ex post opportunism, it is argued that states institutionalize the non-market exchange of control by granting one another informal spheres of national influence over subdivisions within the international organization. 
The limits of control of international organizations

As described in the previous section, it has become popular to analyze the strategic interaction between states and international organizations through the lens of Principal-Agent theory. In this model, a boss (or principal) delegates certain tasks to a subordinate (or agent), who can either act in a way that is good for the boss or shirk in one way or another. The delegation of authority is consequently fraught with problems. For example, the principal might choose the wrong candidate for the job, someone who is more interested in checking facebook than in getting on with the job. Another problem arises when, once the contract is signed, the agent acquires superior information that she might use against the boss' best interests. ${ }^{4}$

This division of labor also makes sense in the international arena. States (the principal) delegate authority to an international organization (the agent) in order to interpret ambiguous rules, to take the blame for unpopular policies, or to centralize policy-relevant expertise (Hawkins, Lake, Nielson et al. 2006, 13-20). Yet the delegation of authority in international politics is fraught with similar delegation problems as in the workplace. Once set up, the international organization's staff or leadership might develop different views about what it should do and how, and it consequently exploits its autonomy against the member states' best interests (agency slack).

Since states may anticipate these delegation problems, this is not where the story ends. There is wide agreement that states limit the risk of shirking by designing mechanisms that align incentives and reduce informational asymmetries between both parties. Scholars typically distinguish between police patrol and fire alarm control mechanisms (McCubbins and Schwartz 1984). For example, the explication and mandatory approval of work

${ }^{4}$ Bendor et al. ((2001)) provide a good overview of theories of delegation in political science. Stone ((2009)) critically discusses the literature on delegation in international politics. 
programs is a police-patrol type control mechanism that takes effect prior to the agent's action. Interest groups that detect and report fraud are fire-alarm type mechanisms that go off when the agent is about to shirk, and that provide states the opportunity to punish and recontract their agent. Thus, the autonomy of international organizations is, in fact, an empirical question that depends on the design of control mechanisms and the credibility of states' threat to invoke them (Pollack 1997, 129).

Some scholars maintain that the control of agents is particularly difficult in the international realm, since international organizations are accountable not to a single, but to a collective principal consisting of two or more states. As a consequence, the credibility of the principal's threat to invoke control mechanisms to change the international organization's action depends on the members' capacity to take collective decisions. This specific characteristic, some argue, potentially gives international organizations substantial autonomy. As Daniel Nielson and Mike Tierney $(2003,249)$ express it:

If actors within the collective principal do not agree on proposed policy changes or institutional reforms, and the agent is cognizant of this disagreement, then the agent may be able to play members of the collective principal against each other. Such a situation makes it difficult for the collective principal to alter, or credibly threaten to alter, the agent's contract. Hence, agents can more easily ignore threats and refuse to modify their behavior. ${ }^{5}$

This holds true even when majority voting facilitates decision-making. Lisa Martin $(2006,144)$ observes:

When state preferences diverge, stretching along the entire policy continuum, there is more likely to be a wide range of proposals that could gain majority approval. This gives the staff [the of an international organization] room for maneuver, as they can choose the proposal within this space that comes closest to their ideal point.

5 Cf. Fritz Scharpf ((1988)) makes a similar argument, which he refers to as the "joint decision trap." 
In other words, the literature on delegation in international politics emphasizes that substantial differences in states' interests impede effective control of international organizations and, ceteris paribus, enhances the organization's autonomy vis-à-vis its members, the collective principal.

\section{Gains from exchange of control}

The finding that diverse preferences among the members of a collective principal impede effective control of an agent stands in contrast to results in political economy about the gains from political exchange. This work on vote trading, also known as logrolling, stipulates that divergent interests create implicit or explicit markets for the trading of political support (Buchanan and Tullock 1962; Tullock 1981).

The central difference between both models is the multidimensionality of policies. Consider a legislature deliberating on a single issue. Absent any contact, each legislator submits a proposal that benefits him at the expense of others, but none of these proposals commands a majority. However, by supporting an issue that our legislator cares less about in exchange for support on another issue that is closer to his heart, all legislators get their proposal passed and, as a result, are better off.

This formal result about the gains from political exchange implies that divergent preferences among the members of a collective principal need not impede the control of an agent. In fact, the divergence of preferences creates potential gains from exchange of political support for the control of an international organization. Consider the following hypothetical situation where state A opposes the organization's liberalization of public companies, while state B faces a similar situation regarding the organization's consumer 
protection policy. In this situation, both states would benefit from supporting each other and compel the organization to be more lenient in both cases.

\section{The industrial organization of international bureaucracies}

Yet gains from exchange like this are difficult to realize. Enforcement problems arise because states do not realize their gains at the same time. Public perception of the issue may change, and the electoral effect of this change is observable only to the government it affects. This induces a form of moral hazard in that one party to the bargain may claim that it can no longer help control the international organization and so attempt to renege. In the face of this commitment problem, states can be expected to devise institutional arrangements that sustain exchanges of political support.

The political economy literature on legislative institutions shows that this can be accomplished by assigning property rights over political jurisdictions. Consider the exchange of political support in the absence of property rights. State B announces that it supports state A's demand that the bureaucracy enforce the liberalization of public companies less rigorously. In exchange for this support, state A announces its support for state B's demand for a more generous consumer protection. After having adopted the consumer protection legislation, state B's administration is replaced with a new government that in spite of its predecessor's promise to support a more lenient policy demands that the international organization step up its effort to liberalize public companies. In other words, states face commitment problems due to their incentive to overturn the substance of a deal through subsequent political action. 
Now consider the same bargain assuming that states have some influence on the international bureaucracy's actions. ${ }^{6}$ State A builds a national chiefdom within the division responsible for the liberalization of public companies, and state B has some political clout in the division responsible for consumer protection. Suppose that, once state B has received support for more generous consumer protection, its new government demands that the international organization step up its effort to break up state-owned companies after all. To make the international organization toughen up the implementation of this policy, state B would have to order the international bureaucracy to pursue this more ambitious objective. Since the division responsible for the liberalization of public companies is part of state A's chiefdom, however, state $\mathrm{B}$ is not in the position to change the international organization's policy. In other words, the informal institutionalization of national spheres of influence within the international organization - that is, states' control the design and selection of an aspect of the international organization's agenda - serves as a mechanism to prevent ex post reneging (Weingast and Marshall 1988, 144).

In short, gains from exchanges exist due to the fact that states place different values on the control of an international organization across various policy areas. Accordingly, different states seek to attain gate-keeping control in those policy areas that they prefer most. Therefore, states can be expected to establish spheres of influences over subdivisions that they intensely prefer.

\footnotetext{
${ }^{6}$ The empirical literature on shows that there are several more or less subtle ways for states to do this, including domestic career rewards and punishments, recruitment requirements that bias staff toward a particular nationality or ideology, or the withholding of funds or expertise. Urpelainen ((2012)) gives a good overview of this literature. These instruments remain largely informal in order to prevent damage to the international organization's and its members' reputations.
} 


\section{Informal Spheres of Influence in the European Union}

The EU, like other international organizations, is based on several legalized interstate agreements that spell out the objectives and rules of cooperation. These agreements concerns first and foremost the establishment of a genuine single market, in which trade among the member states is as easy as trade within them. "Flanking" the single market are policies such as monetary union, competition, common commercial policy, environmental regulation, or consumer protection. Finally, the EU has more limited competences in security policy, immigration, police cooperation, and so on. This range of policies within the EU is considerably wider than that of the average international organization.

This section looks at the European Commission's composition in order to show that it exhibits informal spheres of influence that are controlled by individual member states with strong preferences in this subject area. It first contrasts the Commission's formal set up with actual recruitment and decision-making practices. Against this backdrop, I evaluate the theory's implication that preference outliers control these national chiefdoms - that is, that member states informally influence the agenda of divisions in which they hold intense preference.

\section{The European Commission as an independent agent}

At the EU's core lies the following stylized decision-making process: The Commission, a supranational bureaucracy, is endowed with the exclusive right of legislative initiative. After the official submission of a legislative proposal, governments in the Council of Ministers may adopt, today jointly with the European Parliament, the legal act by majority vote, and they may 
change it only when they are able to attain unanimity for an amendment. National administrations, the European Commission, or both, then typically implement the legal act. The European Court of Justice, in cooperation with domestic courts, enforces compliance with EU law.

The European Commission is, therefore, the EU's principal bureaucracy that helps the member states formulate and implement their legalized agreements. Its primary responsibilities include (1) proposing and developing policies and legislation; (2) executive functions, including secondary legislation and supervision of member state policy implementation; and (3) guarding the legal framework by monitoring compliance with EU law (Nugent 2010, 122133).

Students of the EU usually explain the delegation of these powers to the Commission with the vocabulary of Principal-Agent theory (Pollack 2003). Since international cooperation generates benefits as well as adjustment costs for different domestic groups, governments might suddenly face incentives to give in to the demand of certain domestic interests to renege on an interstate agreement. To enhance the credibility of their commitment to cooperation, they consequently delegate the authority to formulate and implement their agreements to an agent that is shielded from these ad-hoc influences (Majone 1994; Moravcsik 1998). Because they are more removed from domestic interests, so the logic of the argument, supranational institutions are more immune to ad-hoc influences than national administrations (Hawkins, Lake, Nielson et al. 2006, 18-19).

Since the delegation of authority to the Commission is supposed to enhance the member states' commitments, EU treaties put strong emphasis on this agent's independence. The Treaty on European Union (Article 17) states: 
In carrying out its responsibilities, the Commission shall be completely independent. [The] members of the Commission shall neither seek nor take instructions from any Government or other institution, body, office or entity. They shall refrain from any action incompatible with their duties or the performance of their tasks.

Consequently, the treaties emphasize that the Commission's internal decisionmaking processes be shielded from ad-hoc influences. On top of the Commission's administrative level, the services, is a political level composed of the President and a college of Commissioners, each of whom is nominated by a member states and responsible for a specific portfolio. The treaty stipulates that "[the] members of the Commission shall be chosen on the ground of their general competence and European commitment from persons whose independence is beyond doubt. (Article 17)" It goes on emphasizing that they "shall refrain from any action incompatible with their duties. Member States shall respect their independence and shall not seek to influence them in the performance of their tasks. (Article 245)"

A number of control mechanisms are supposed to prevent the Commission from systematically overstepping its delegated discretion. For example, various governmental committees - the so-called "comitology" - monitor the implementation of policies by the Commission. In addition, other supranational institutions such as the European Parliament and the Court of Auditors monitor the Commission's behavior. The European Court of Justice reviews the legality of its actions, which it may declare void, and may also rule on the Commission's failure to act on its responsibilities under the treaties (Pollack 1997, 114-116). 


\section{The Commission in reality}

The EU's formal rules suggest a principal-agent relationship between the member states and the Commission. The member states deliberately delegated the authority to implement their legalized agreements to this supranational bureaucracy. Fully aware of their temptation to manipulate their agent, they officially pledged to guarantee its complete independence from national and other ad-hoc influences. A number of external control mechanisms hinder the Commission from overstepping its discretion.

In practice, however, the Commission was never able to assert its independence in full. I now contrast its official set-up with the practices that developed in reality in order to show how informal spheres of national influence developed inside the Commission. Immediately after the Commission had been set up in the late 1950s and early 1960s, the Commissioners established personal offices, the original function of which was to prepare decisions in the college of Commissioners (Krenzler 1974). But these offices, the cabinets, quickly assumed additional tasks. Composed mainly of fellow countrymen, they served as a transmission belt between the Commissioner and her home country, and the member states themselves did not shy away from using these ties to raise objections against legislative proposals in the making. For example, in an internal meeting of undersecretaries in the late 1960s, the German economics ministry observed that other countries made much better use of "their" Commissioners, and urged that it was necessary to follow suit in order to be able to voice specific concerns about Commission initiatives (Bundesministerium für Wirtschaft 1967). The cabinets permitted the Commissioner, to whom they were directly responsible, to intervene in the work of the Commission services (Coombes 1970, 255). Describing the development of "national enclaves" within the Commission, a close observer observes in 1964 a strong "discrepancy between 
institutional theory of the Communities... and the administrative practice of the Commission (Siotis 1964, 249).

Fearing this degradation of the Commission's supranational character and the collaboration between college and civil servants, its first president Walter Hallstein was keen to keep the cabinets' size as small as possible. A member of the Hallstein Commission (Lemaignen 1964, 49-50) explains:

The President [Hallstein] was categorically opposed to the numerous cabinets: he said he did not want the Commissioners to become "mediatized" by their immediate collaborators. Beyond doubt, he also considered that because everyone seemed to quietly agree that cabinet members ought to be of the same nationality as the Commissioner, their excessive multiplication risked creating an internal nationalism within the cabinet.

Nevertheless, the Commissioners found various ways to work around the president's order. The size and influence of the cabinets consequently grew considerably toward the end of the decade (Bitsch 2007, 200; Ritchie 1992, 104). Thus, when the college decided in the early 1970s to restrict the number of cabinet members, the Commissioners did not adhere to their own rule (Endo 1999, 44). The cabinets grew dramatically from an average of four in the late 1960s to fourteen members by the mid-1970s (Michelmann 1978, 495; Poullet and Deprez 1976, 53), and increasingly became a channel for the member states to raise objections against proposals in the making, and for the Commissioners to subsequently intervene in the work of the services (European Communities 1979, 56).

Although the Presidency of Jacques Delors from 1985 until 1995 is often hailed as the second heyday of the Commission, these years only served to enhance the power of the cabinets and intensify frictions between the college and the services. For Delors, his personal office was a means to do an end-run around slow internal decision-making, and the members of his cabinet, 
headed by Pascal Lamy, were considered particularly patronizing, even brutal, towards other Commissioners and the Commission services (Ross 1994, 63-68). Other Commissioners seized the opportunity by strengthening their own cabinets' power over the services. An internal report in 1991 notes an ever-increasing interference by cabinets into the work and tasks that are incumbent on the services (Commission des Communautés Européennes 1991, 4). Another internal report (Commission Européenne 1994, 36) about the Commission's efficiency drawn up by the services points to the cabinets' increasing meddling with the Directorate Generals' work, and demands

... first of all, to improve the connection [embrayage] between the institution's political and the administrative level, and in this context to limit the excessive interference of the member states.

The system of cabinets came under fire when various incidents of mismanagement and nepotism under Delors' and, subsequently, Jacques Santer's Presidencies put the Commission under increased public scrutiny (Commission Européenne 1994, chap 2; European Commission 1998). The Commission's services set up a task force and the European Parliament a Committee of Independent Experts to inquire into the cause of the Commission's mismanagement. The report criticized that cabinets are "composed exclusively or predominantly of persons of the same nationality as the commissioner" and consequently demanded clearer rules and criteria for the appointment of individuals to the cabinets as well as limits on the cabinets' size and quotas to ensure their multinational character (Committee of Independent Experts 1999, 23). A former member of one of these cabinets (Eppink 2007, 115-116, 119) describes their role as gate-keepers and transmission belts.

[A] member of cabinet has to be a kind of internal spy. To do this job, he has to know what is going on in the DG - and this is not always straightforward... As soon as a draft reaches the political 
level - in other words, the level of cabinets - national interests come more strongly into play. During my studies, I had been taught that a Commissioner works for the greater good of all Europeans. Like many things taught at school, this is not entirely true... [All] too often national reoccupations are introduced into the debate via the backdoor of the Commissioner's cabinet.

There have been a number of attempts to reform the cabinet system. Under Commission President Romano Prodi each cabinet was supposed to include staff of at least three nationalities comprising no more than six senior members (Agence Europe 1999; Prodi 1999). His successor Barroso decreed that at least three members had to be recruited from the services (Peterson 2010, 5). Although the cabinets became more multinational at the core (Egeberg and Heskestad 2010, 780), the actual effects of these changes are mixed. Commissioners once again found various ways around the rules. Peterson (2010, note 2) notes that there is currently considerable ambiguity with respect to the role of personal advisors, who are not official members of the cabinet. Although the number of cabinet members has gone down officially, the Commissioners clearly get additional personal help. "By a liberal account," he notes, "most cabinets could be viewed as having at least 17 members."

Thus, the qualitative data about actual decision-making practices within the Commission strongly suggest the existence of national spheres of influence within the Commission. Statistical evidence confirms this finding. In an analysis of 70 legislative proposal introduced by the Commission between 1996 and 2000, Robert Thomson $(2008$, 187) finds that the nationality of the responsible Commissioner has a substantial effect on the Commission's position vis-à-vis the member states. In other words, it shifts the Commission's position closer to that of the Commissioner's home country and farther away from other member states' positions. This findings suggest that, once appointed, Commissioners are not entirely insulated from national 
pressures and, in fact, build national chiefdoms to control their subdivision's policy.

The distribution of posts in the Commission

Why do member states tolerate national spheres of influence within the Commission? Why don't they abolish the member states' representation within the Commission, or design it in ways that its officials can fight off the member states' interference into their work? I argue that the member states' realize gains from exchange of political support by granting one another agenda control over the organization's individual subdivisions. This implies that preference outlier instead of median countries control national chiefdoms within the Commission.

Arndt Wonka's extensive empirical study of the appointment of Commissioners since 1958 shows that the member states strategically secure portfolios that they intensely prefer for Commissioners of their nationality. ${ }^{7}$ Focusing on party preference, he finds that member states that are governed by a left-wing party at the time of appointment predominantly occupy subdivisions, Directorate Generals, that deal with the negative externalities of the single market, namely consumer protection, environment, social policy, and so on, whereas conservative parties strongly dominate the Commission's Directorate General responsible for Agriculture. Similar patterns exist at the

\footnotetext{
${ }^{7}$ Until 1993, the Council had to agree unanimously on the entire college including its president. Appointments of new Commissions were consequently preceded by intense negotiations among the member states about the prospective president as well as the distribution of posts and portfolios. The Maastricht Treaty gave the European Parliament and the prospective Commission president a formal say in the appointment procedure. Today, the member states first appoint the president of the Commission before all of them draw up a list of candidates for the post of Commissioners. Both Parliament and the Commission president have the power to veto this list. These changes to the appointment procedure notwithstanding, the member states have retained considerable power the member states jointly set the agenda by proposing a composition of the college that they, the Parliament, and all actors eventually vote upon ((Wonka 2007, 170-173)).
} 
member state level. To give but a few examples: countries such as Germany and Great Britain that are "net contributors" strongly dominate the Directorate General responsible for the Budget in order to prevent lavish spending. Countries that share a border with membership candidates have always occupied the division responsible for EU enlargement (Wonka 2008, 121-130). Accordingly, it became evident very early on that some Directorate Generals more or less “belonged" to certain member states (Cini 1996, 126).

One might object that national chiefdoms exist because officials from countries with a special interest in a specific policy have more expertise in this area (Krehbiel 1991). Thus, officials from land-locked Austria simply lack substantive knowledge about the intricacies of deep-sea fisheries. Although both explanations need not be mutually exclusive, the evidence does not sustain this objection. If expertise were the main selection criterion, member states would appoint Commissioners with previous experience in the subject matter. Wonka $(2007,178-9)$ finds, however, that the member states prefer people with a visible political career to technocrats with a reputation for substantive expertise. In fact, they primarily appoint Commissioners who share the party affiliation of the government in office. The reason, he maintains, is for the member states to avoid the imposition of materially and politically costly EU regulations.

Summing up, the evidence presented in this section suggests that member states grant one another spheres of influence within the European Commission. As demonstrated with the description of the cabinet system, these national chiefdoms hold agenda-setting power over the Commission's Directorate Generals, and the member states do not shy away from using this influence for their purposes. Corroborating the theory, I found that Commissioners tend to head national chiefdoms in policy areas in which their home country holds intense preferences. 


\section{Discussion: National Chiefdoms Outside the EU}

One might object that this case selection overestimates the theory's plausibility, since the EU's broad scope with policies ranging from consumer protection over agriculture to monetary union and a common security policy offers plenty opportunities for exchange. Quite possibly international organizations with narrower scope, everything else being equal, are less likely to exhibit national spheres of influence. It can also be argued that the EU is a hard case for the theory. Headed by influential presidents, allied with other supranational actors, and partly drawing on own resources, the Commission is more autonomous and, therefore, better able to fight off national influences than many other international administrations. Accordingly, tacit deals among governments in terms of controlling different aspects of an international organization's output are not limited to the EU.

However, a cursory look at appointments and recruitment in international organization illustrates the theory's plausibility in other contexts. The most prominent example of tacit trades of control is perhaps the understanding between the US and the EU that a European national chair the IMF, whereas an American citizen heads the World Bank. There are other, more subtle examples.

Consider the United Nations. The Secretariat, staffed by international civil servants, carries out a myriad of duties ranging from the administration of peacekeeping operations to making studies about different countries' economic and social trends. According to the Charter, the secretariat is entirely independent and, to avoid any national clustering, recruited on a wide geographical basis (Jonah 2008, 166). In reality, there is "a continuing disparity between the formal or legal code of conduct and the operational code" (Meron 1981, 910). Recruitment of senior staff is guided by an informal 
agreement among the permanent members of the Security Council that emerged in the midst of the Cold War when the they agreed "to ask" that a national of each be appointed as Assistant Secretary-General. The other four members, France, Britain, the United States and China, also staked their respective claims to a position at the highest administrative level (Ziring, Riggs, and Plano 2000, 117-118). Nationals of the same country or a certain group of countries usually inherit these posts (Meron 1981-1982, 862). As the number of top Secretariat positions (Under- and Assistant SecretariesGeneral) increased, the practices of preserving such appointments was extended to other governments, leading to what a close observer called "national monopolies on senior posts" that resulted in a "fiefdom mentality" (Rivlin 1993, 9) and "national preserves" (Meron 1977, 93-98) over certain toplevel posts in the Secretariat. As two close observer note

[Under- and Assistant Secretaries-General] posts have become associated with certain nationalities, or regional or language groups, and although there may be "trades" affecting which nationality or group is represented in which post, the overall balance within the upper levels is likely to change only slowly (Finger and Mugno, in (Ameri 1996, 250).

Interestingly, there is variation in the prevalence of informal spheres of national influence. In fact, other international organizations such as the World Trade Organization (WTO) appear to have developed implicit norms against the trading of control of its secretariats' divisions. The WTO rests on agreements that cover, among other things, market access, subsidies, antidumping, agriculture, intellectual property rights, trade and environment, and technical trade barriers. Its Secretariat, which comprises sixteen subdivisions that are supposed to engage in helping the members to monitor compliance with the existing agreements, is supposed to be the guardian of the treaties and to assist and support WTO members within the framework of this mission. Article VI of the agreement establishing the WTO stipulates that 
it does not "seek or accept instructions from any government or any other authority external to the WTO..."

The lack of specific appointment procedure and official national quotas that constrain recruitment for posts within the WTO secretariat should facilitate the trading of control through national chiefdoms. Indeed, there is more sensitivity for an appropriate regional balance at the top level as well as an understanding that the US and the EU as the two most influential members will always have one Deputy Director-General. However, there is little evidence that the member states grant one another influence over divisions that lie close to their heart. On the contrary, two close observers of the WTO note "a tacit agreement that no one chairs a committee on a subject on which his country has strong interests; thus Australia and Switzerland would not want, or be asked, to chair a committee on agriculture" (Yi-chon and Weller 2004, 257-259).

This cursory discussion of official and informal appointment procedures in important international organizations illustrates that the phenomenon of informal spheres of influences within international organizations is not limited to the EU. Importantly, some international organizations exhibit more national chiefdoms than others. The conclusion discusses why this might be the case.

\section{Conclusion}

The last decade has witnessed an increasing popularity of Principal-Agent approaches to international organizations. In this view, states (the principal) delegate the implementation of a legalized agreement to an international organization (the agent). The conventional wisdom about states' capacity to 
control international organizations is that differences among the member states impede control and consequently enhance the agent's autonomy, whereas agreement allows for effective control and limited autonomy. Contrary to this conventional wisdom, this article argues that conflicts among states need not impede effective control. On the contrary: it harbors gains from the exchange of control over an organization. To reap these gains, states grant one another agenda control over their organization's most preferred subdivisions. As a result, international organizations exhibit informal spheres of influence, or national chiefdoms. The article demonstrated the theory's plausibility using the example of the EU. However, the cursory review of appointments and recruitment in other international organization demonstrates that this phenomenon is by no means limited to the European case, and that there is variation in the extent that international organization exhibit national chiefdoms.

What explains an international organization's propensity to develop national chiefdoms within it? One possibility is, as mentioned above, that the multidimensionality of an organization in relation to the diversity of interests among member states determines the existence of national chiefdoms. A broader scope and fewer cleavages among states (as in the EU) provide more opportunities for the exchange control within an international organization, whereas a relatively narrower scope and more cleavages among the members (as in the WTO) offer fewer opportunities. Another, simpler reason could be that the WTO secretariat has far less discretion over policies than the European Commission. In this sense, states gain from exchanging control only when there is anything to control to begin with.

The theory has important implications for our understanding of international organizations. First, it cautions against approaching, as Principal-Agent theory typically does, international organizations as unitary actors with a 
uniform preference for autonomy. If states seize opportunities for trading informal control over the organization's division, these are, in fact, empirical questions that cannot be imputed to an international organization.

Second, and related, the theory suggests that states have more informal control over international organizations than their formal rules and anecdotes about runaway international bureaucracies have us believe. This does not mean that national chiefdoms impede cooperation. Rather, informal influence allows countries to curb and push a division's activism, or to influence the content of its policy.

Third, where prominent theories of informal governance attribute informal national influences on an international organization to power asymmetry among member states, this article presents a transaction cost-based argument for the existence of this phenomenon. Yet both arguments need not be mutually exclusive. Since the number and value of the "goods" (i.e. divisions) to be distributed might be scarce, states will bargain and fight over the precise distribution of national chiefdoms among them. In this fight, powerful states can be expected to get the first pick and occupy more divisions than their weaker cooperating partners. 


\section{References}

Agence Europe. 1999. "Romano Prodi sets out his intention over reorganisation of European Commission." June 3.

Ameri, Houshang. 1996. Politics of Staffing the United Nations Secretariat. New York: Peter Lang.

Axelrod, Robert. 1984. The Evolution of Cooperation. New York, NY: Basic Books.

Bendor, J., A. Glazer, and T. Hammond. 2001. "Theories of Delegation." Annual Review of Political Science no. 4 (1):235-69.

Bitsch, Marie-Thérèse. 2007. "The College of Commissioners: A new type of public authority." In The European Commission, 1958-1972. History and Memories, edited by Michel Dumoulin, 181-204. Brussels: European Commission.

Buchanan, James, and Gordon Tullock. 1962. The Calculus of Consent. Logical Foundations of Constitutional Democracy. Ann Arbor: University of Michigan Press.

Bundesministerium für Wirtschaft. 1967. Staatssekretärbesprechung am 10. Juli 1967. Kontakte deutscher Dienststellen zu den Bediensteten deutscher Staatsangehörigkeit bei der Kommission, May 31, B102, Band 61703, Bundesarchiv Koblenz.

Cini, Michelle. 1996. The European Commission. Leadership, organisation and culture in the EU administration. Manchester: Manchester University Press.

- - 2000. "Administrative Culture in the European Commission: The Cases of Competition and Environment." In At the Heart of the Union. Studies of the European Comission. Second Edition, edited by Neill Nugent, 51-72. Houndmills: Macmillan.

Commission des Communautés Européennes. 1991. Rapport de la Task Force Screening à la Commission, March 19, SEC (91) 551.

Commission Européenne. 1994. Reflexions sur l'efficacité de l'institution et de son administration. Rapport établi conformement au mandat confié à M. Philippe Petit-Laurent, November 9.

Committee of Independent Experts. 1999. Second Report on Reform of the Commission. Analysis of current practice and proposals for tackling mismanagement, irregularities and fraud. Volume I. 10 September 1999.

Coombes, David. 1970. Politics and Bureaucracy in the European Community. A Portrait of the Commission of the E.E.C. London, UK: George Allen and Unwin LTD.

Egeberg, Morten, and Andreas Heskestad. 2010. "The Denationalization of Cabinets in the European Commission." Journal of Common Market Studies no. 48 (4):775-786.

Endo, Ken. 1999. The Presidency of the European Commission under Jacques Delors. The Politics of Shared Leadership. Houndmills: MacMillan.

Eppink, Derk-Jan. 2007. Life of a European Mandarin. Inside the Commission. Tielt: Lannoo.

European Commission. 1998. Rapport du Groupe de Reflexion sur la politique du Personnel (Williamson Report). 6 novembre 1998.

European Communities. 1979. Proposals for Reform of the Commission of the European Communities and its Services. Report made at the request of the Commission by an 
independent review body under the chairmanship of Mr. Dirk Spierenburg, September 24, accessed October 31, 2012, http://aei.pitt.edu/993/.

Garrett, Geoffrey, and George Tsebelis. 1996. "An Institutional Critique of Intergovernmentalism." International Organization no. 50 (2):269-299.

Haas, Ernst B. 1958. The Uniting of Europe: Political, Social and Economic Forces. 1950-1957. Stanford: Stanford University Press.

. 1961. "International Integration. The European and the Universal Process." International Organization no. 15 (3):366-392.

Hawkins, Darren G., David A. Lake, Nielson; Daniel L., and Michael J. Tierney. 2006. Delegation and Agency in International Organizations. Cambridge, UK: Cambridge University Press.

Hawkins, Darren, David Lake, Daniel Nielson, and Michael Tierney. 2006. "Delegation under anarchy: states, international organizations, and principal-agent theory." In Delegation and Agency in International Organizations, edited by Darren Hawkins, David Lake, Daniel Nielson and Michael Tierney, 3-38. Cambridge, UK: Cambridge University Press.

Jonah, James O.C. 2008. "Secretariat: Independence and Reform." In The Oxford Handbook on the United Nations, edited by Sam Daws and Thomas G. Weiss, 160-174. Oxford: Oxford University Press.

Keohane, Robert 0. 1984. After Hegemony. Cooperation and Discord in the World Political Economy. Princeton, NJ: Princeton University Press.

Kleine, Mareike. forthcoming-a. "Knowing Your Limits: Informal Governance and Judgment in the EU." Review of International Organizations.

- - - forthcoming-b. Making Cooperation Work. Informal Governance in the European Union and Beyond. Ithaca, NY: Cornell University Press.

Krehbiel, Keith. 1991. Information and Legislative Organization. Ann Arbor, MI: University of Michigan Press.

Krenzler, Horst Günther. 1974. "Die Rolle der Kabinette in der Kommission der Europäischen Gemeinschaft." Europarecht (1):75-79.

Lemaignen, Robert. 1964. L'Europe au Berceau. Souvenirs d'un Technocrate. Paris: Plon.

Majone, Giandomenico. 1994. "The Rise of the Regulatory State in Europe." West European Politics no. 17 (3):77-101.

Martin, Lisa L. 2006. "Principal preferences, structure, decision rules, and private benefits: the case of IMF conditionality." In Delegating Authority to International Organizations, edited by Darren Hawkins, David A. Lake, Daniel Nielson and Michael J. Tierney, 140-164. Cambridge: Cambridge University Press.

Martin, Lisa L., and Beth Simmons. 1998. "Theories and Empirical Studies of International Institutions." International Organization no. 52 (4):729-757.

McCubbins, Mathew D., and Thomas Schwartz. 1984. "Congressional Oversight Overlooked: Police Patrols versus Fire Alarms." American Journal of Political Science no. 28 (1):165-179.

Meron, Theodor. 1977. The United Nations Secretariat. Toronto: Lexington Books.

. 1981. "In RE Rosescu and the Independence of the International Civil Service." American Journal of International Law no. 75 (4):910-925. 


\section{Trading Control}

1981-1982. "The Role of the Executive Heads." NYU Journal of Internaitonal Law and Politics no. 14:861-869.

Michelmann, Hans J. 1978. "Multinational Staffing and Organizational Functioning in the Commission of the European Communities." International Organization no. 32 (2):477-496.

Moravcsik, Andrew. 1998. The Choice for Europe. Social Purpose and State Power from Messina to Maastricht. Ithaca, NY: Cornell University Press.

Nielson, Daniel L., and Michael J. Tierney. 2003. "Delegation to International Organizations: Agency Theory and World Bank Environmental Reform." International Organization no. 57 (2):241-276.

Nugent, Neill. 2010. The Government and Politics of the European Union. 7th ed. Basingstoke: Palgrave Macmillan.

Peterson, John. 2010. "Mission? Gestion? Cabinets in the Barroso Commission." Paper prepared for presentation at the Political Studies Association Conference in Edinburgh, April 1.

Pevehouse, Jon, Timothy Nordstrom, and Kevin Warnke. 2004. "The Correlates of War 2 International Governmental Organizations Data Version 2.0." Conflict Management and Peace Science no. 21 (2):101-119. 10.1080/07388940490463933.

Pollack, Mark A. 1997. "Delegation, agency and agenda setting in the European Community." International Organization no. 51 (1):99-134.

——-. 2003. The Engines of European Integration. Oxford, UK: Oxford University Press.

Poullet, Edouard, and Gérard Deprez. 1976. Struktur und Macht der EG-Kommission. Die Kommission im System der Europäischen Gemeinschaft. Bonn: Europa Union Verlag.

Prodi, Romano. 1999. Intervention of Prof. Prodi in European Council, 3rd June 1999. NIO/99/248.

Ritchie, Ella. 1992. "The Model of French Ministerial Cabinets in the Early European Commission." In Die Anfänge der Verwaltung der Europäischen Gemeinschaften, edited by Erk Volkmar Heyen, 95-106. Baden-Baden: Nomos.

Rivlin, Benjamin. 1993. "The Changing International Political Climate and the Secretary-General." In The Challenging Role of the UN Secretary-General, edited by Benjamin Rivlin and Leon Gordenker, 3-21. Westport: Praeger.

Ross, George. 1994. "Inside The Delors Cabinet." Journal of Common Market Studies no. 32 (4):499-523.

Scharpf, Fritz W. 1988. "The Joint-Decision Trap: Lessons From German Federalism ad European Integration." Public Administration no. 66 (3):239-278.

Siotis, Jean. 1964. "Some Problems of European Secretariats." Journal of Common Market Studies no. 2 (3):222-250.

Stone, Randall W. 2009. "Institutions, Power, and Interdependence." In Power, Interdependence, and Nonstate Actors in World Politics, edited by Helen V. Milner and Andrew Moravcsik. Princeton: Princeton University Press.

- 2011. Controlling Institutions. International Organizations and the Global Economy. Cambridge, UK: Cambridge University Press. 
Thomson, Robert. 2008. "National Actors in International Organizations: The Case of the European Commission." Comparative Political Studies no. 41 (2):169-192.

Tullock, Gordon. 1981. "Why So Much Stability?" Public Choice no. 37 (2):189-202.

Urpelainen, Johannes. 2012. "Unilateral Influence on International Bureaucrats: An International Delegation Problem." Journal of Conflict Resolution no. 56 (4):704-735.

Weingast, Barry R., and William J. Marshall. 1988. "The Industrial Organization of Congress; or, Why Legislatures, Like Firms, Are Not Organized as Markets." Journal of Political Economy no. 96 (1):132-163.

Wonka, Arndt. 2007. "Technocratic and independent? The appointment of European Commissioners and its policy implications." Journal of European Public Policy no. 14 (2):169189.

2008. Die Europäische Kommission. Supranationale Bürokratie oder Agent der Mitgliedstaaten? Baden-Baden: Nomos.

Yi-chon, Xu, and Patrick Weller. 2004. The Governance of World Trade. International Civil Servants and the GATT/WTO. Cheltenham: Edward Elgar.

Ziring, Lawrence, Rovert Edwon Riggs, and Jack C. Plano. 2000. The United Nations: international organization and world politics. Fort Worth: Harcourt Publishers. 
Trading Control

Eqs 


\section{Recent LEQS papers}

Aranki, Ted \& Macchiarelli, Corrado. 'Employment Duration and Shifts into Retirement in the EU' LEQS Paper No. 58, February 2013

De Grauwe, Paul. 'Design Failures in the Eurozone: Can they be fixed?' LEQS Paper No. 57, February 2013

Teixeira, Pedro. 'The Tortuous Ways of the Market: Looking at the European Integration of Higher Education from an Economic Perspective' LEQS Paper No. 56, January 2013

Costa-i-Font, Joan. ' Fiscal Federalism and European Health System Decentralization: A Perspective' LEQS Paper No. 55, December 2012

Schelkle, Waltraud. 'Collapsing Worlds and Varieties of welfare capitalism: In search of a new political economy of welfare' LEQS Paper No. 54, November 2012

Crescenzi, Riccardo, Pietrobelli, Carlo \& Rabellotti, Roberta. 'Innovation Drivers, Value Chains and the Geography of Multinational Firms in European Regions' LEQS Paper No. 53, October 2012

Featherstone, Kevin. 'Le choc de la nouvelle? Maastricht, déjà vu and EMU reform' LEQS Paper No. 52, September 2012

Hassel, Anke \& Lütz, Susanne. 'Balancing Competition and Cooperation: The State's New Power in Crisis Management' LEQS Paper No. 51, July 2012

Garben, Sacha. 'The Future of Higher Education in Europe: The Case for a Stronger Base in EU Law' LEQS Paper No. 50, July 2012

Everson, Michelle. 'A Technology of Expertise: EU Financial Services Agencies' LEQS Paper No. 49, June 2012

Cherrier, Nickolas. ‘EU Diplomacy at 27: United in Diversity?' LEQS Paper No. 48, May 2012

White, Jonathan. 'Parallel Lives: Social Comparison Across National Boundaries' LEQS Paper No. 47, January 2012

Meyer, Niclas. 'Political Contestation in the Shadow of Hierarchy' LEQS Paper No. 46, January 2012

Hyman, Richard. 'Trade Unions, Lisbon and Europe 2020: From Dream to Nightmare' LEQS Paper No. 45, December 2011

Wagner, Peter. 'The democratic crisis of capitalism: Reflections on political and economic modernity in Europe' LEQS Paper No. 44, December 2011

Chalmers, Damian \& Chaves, Mariana. 'The Reference Points of EU Judicial Politics' LEQS Paper No. 43, September 2011

Hassel, Anke. 'The paradox of liberalization - Understanding dualism and the recovery of the German political economy' LEQS Paper No. 42, September 2011

Hancké, Bob. 'Endogenous Coordination: Multinational Companies and the Production of Collective Goods in Central and Eastern Europe' LEQS Paper No. 41, August 2011 


\section{LEQS}

European Institute London School of Economics Houghton Street WC2A 2AE London

Email: euroinst.LEQS@lse.ac.uk

http://www2.lse.ac.uk/europeanInstitute/LEQS/Home.aspx

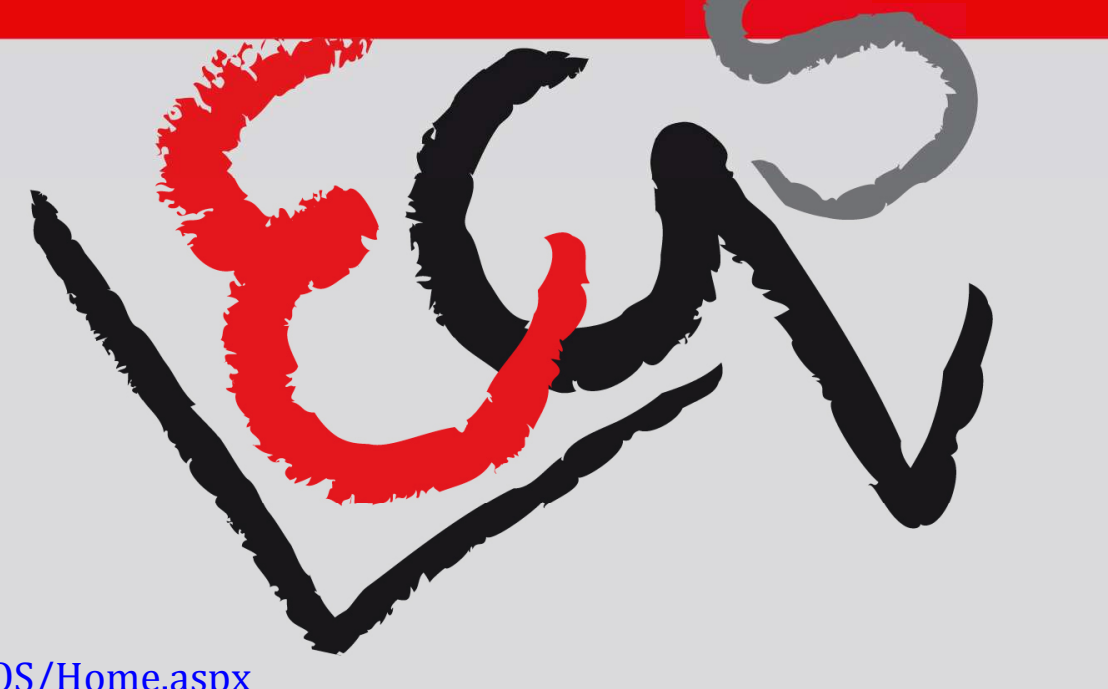

